\title{
DYNAMICS OF THE ADOPTION OF IMPROVED AQUACULTURE TECHNOLOGIES AMONG FISH FARMERS IN LAGOS STATE, NIGERIA
}

\section{Olalekan Jacob Olaoye ${ }^{*}$, Godfrey Nnamdi Onyenoro Ezeri², Yemi Akegbejo-Samsons ${ }^{2}$, Joseph Mubo Awotunde ${ }^{3}$, and Wahab Gbenga Ojebiyi ${ }^{3}$}

\author{
${ }^{1}$ Agricultural Media Resources and Extension Center, Federal University of Agriculture, Abeokuta \\ ${ }^{2}$ Department of Aquaculture and Fisheries Management, Federal University of Agriculture, Abeokuta \\ ${ }^{3}$ Department of Agricultural Extension and Rural Development, Federal University of Agriculture, Abeokuta \\ *Corresponding Author, Email: olaoyeoj@funaab.edu.ng
}

\section{ARTICLE INFO}

Received: 28 January 2016

Received in revised form: 12 March 2016

Accepted: 7 April 2016

Available online: 2 May 2016

\begin{abstract}
The study assessed the adoption of improved aquaculture technologies among fish farmers in Lagos State, Nigeria. A total of 90 fish farmers were sampled through the multistage sampling technique. A validated and pretested interview schedule was used to obtain primary information from the fish farmers. Obtained data were analyzed using descriptive and inferential statistics. Results obtained revealed that more than half and about one-third of the fish farmers sourced credit facilities from cooperative societies and Esusu, respectively, while almost all sold their fishes as smoked fish. Higher proportions of the fish farmers were aware, tried and adopted most of the improved aquaculture technologies with some of the fish farmers also discontinuing most of the previously adopted technologies. The findings of the study also reported that the fish farmers had positive attitude towards the adoption of improved aquaculture technologies. Results of regression analysis revealed that secondary occupation of the fish farmers $(\beta=-0.324, p<0.01)$, annual income level $(\beta=-0.471, p<0.05)$, cost of pond construction $(\beta=0.477, p<0.05)$ and total profit realized $(\beta=-0.466, p<0.05)$ were significant predictors of the adoption of improved technologies by the fish farmers with an R2 implying that $46.0 \%$ of the variability in the fish farmers' adoption of improved aquaculture technologies is explained by the socio-economic and production characteristics of the fish farmers. The study concluded that the adoption of improved aquaculture technologies is dynamic and highly influenced by the socio-economic characteristics of the fish farmers which also change with time. It is therefore recommended that technologies that received low level of adoption or which discontinued after earlier adoption should be worked on so that the adoption of those technologies would translate to increased income level of fish farmers, reduced cost of pond construction and increased profit of the fish farmers.

Olaoye, O. J., Ezeri, G. N. O., Akegbejo-Samsons, Y., Awotunde, J. M., Ojebiyi, W. G. (2016): Dynamics of the adoption of improved aquaculture technologies among fish farmers in Lagos State, Nigeria. Croatian Journal of Fisheries, 74, 56-70. DOI: 10.1515/cjf-2016-0012
\end{abstract}




\section{INTRODUCTION}

Fishery continues to maintain its crucial position through its contribution to the agriculture's share of gross domestic product (GDP) in Nigeria. Fishery subsector was reported to have contributed an average of about $10 \%$ of agricultural GDP between 2008 and 2012 (Food and Agriculture Organization - FAO, 2013). Fisheries are also an enviable subsector which provides employment to a large proportion of the nation's population (about 65-70\%), especially those in riverine and other fishing communities (Areola, 2007; Olaoye, 2010; Shettima et al., 2014). This is aside from its importance in the provision of quality dietary protein (Adewuyi et al., 2010), which is the cheapest when compared with other animal sources of protein. The nation's human population and growth rates of livestock production increasing at about $4-5 \%$ and $2-3 \%$ respectively (Akegbejo-Samsons, 1997) are a reflection of the fact that meeting the animal protein need of Nigerians is a problem. Based on the benefits derived by humans and animals from fish and its products, there is a high demand for fish in Nigeria.

Nigerians have been reported to be one of the largest consumers of fish and fish products (Kudi et al., 2008; Federal Department of Fisheries - FDF, 2008) and this has led the country to resort to massive importation of frozen fish, thereby spending billions of Nigerian Naira that could have been used on developmental purposes on fish exportation. Based on this, the country became popular as one of the largest importers of fish among developing countries (Tunde et al., 2015; Adewuyi et al., 2010). This is attributed mainly to the fact that local fish production could not meet the fish demand in the country due to the subsistence level of production practiced by artisanal fisherfolk who are the primary local producers of fish in Nigeria (Olaoye, 2010). Other attributes of artisanal fishing include lack of infrastructural facilities, adequate funds for the procurement of fishing paraphernalia and basic human needs such as cold storage for proper housing, good/ hygienic drinking water and sanitation (Oladimeji et al., 2013; Kolawole et al., 2010). This made Olaoye et al. (2013) submit that it is almost impossible for the poverty-stricken Nigerians to meet their animal protein needs.

It is worthy of note that fish production in Nigeria is from three major subsectors: artisanal, aquaculture and industrial (Adewuyi et al., 2010). Artisanal fishing has been noted to contribute the largest proportion because the majority of the fishers in Nigeria are artisanal fishers operating with crude fishing tools and implements, little or no credit facilities, and lack of skills. According to an FDF (2009) report, artisanal fish production contributed $85.5-89.5 \%$, while aquaculture and industrial production stood at $5.5-12.0 \%$ and $2.5-5.0 \%$ of the total local fish production in Nigeria, respectively. Contribution of aquaculture has been reported to be on the increase since 2001 according to Ifejika and Ayanda (2012) who reported that aquaculture fish production increased to
$14.5 \%$ in 2010.

Nigeria is blessed with substantial marine and inland fisheries resources upon which fish production is highly dependent (Olatunji and Olah, 2012). In support of this fact, FDF (2007) noted that Nigeria is endowed with over 14 million hectares of reservoirs, lake, flood plains, ponds and major rivers. Out of these, only about 1.75 million hectares equivalent to only about $12.5 \%$ is available and suitable for aquaculture (Food and Agriculture Organization - FAO, 2006). Tobor (1994), however, noted that less than one-fifth of the available land for aquaculture is currently under cultivation. Till date, the situation remained unchanged. Additionally, FAO (2013) estimated the major rivers and lakes at 11.7 million hectares, which is about $12.8 \%$ of the total surface area of Nigeria. Oladimeji et al. (2013) added that the nation is endowed with coastline of about $800 \mathrm{~km}$, a continental shelf of about $256000 \mathrm{~km}^{2}$ and exclusive economic zone of $321.4 \mathrm{~km}$.

Despite the abundant human and non-human resources that the nation is blessed with, the country is yet to bridge the gap between the demand and supply of fish, thereby making the nation one of the protein deficient nations. This study believes that aquaculture has the tendency to contribute significantly to the local fish production in the country if improved aquaculture technologies (saving resources that are scarce) were adopted by the fish farmers. Improved aquaculture technologies could cover fish management areas such as fish enclosure technologies, neutralizers, fertilizers, fish stock selectivity, fish stock management, fish nutrition technologies, integration, pond bottom excavation, fish culture systems, fish harvesting gear system and drainage systems, among others. Adoption is a dynamic process which implies the fact that a previously adopted technology can later be discontinued while a previously rejected technology can later be adopted. Also, the adoption of a new technology may lead to the discontinuation of a previously adopted technology, especially if the latter is superior to the former in terms of productivity and per unit cost of production, and also if it has comparative advantages. The importance of adoption studies are to quantify the number of technology use over time, determine extension requirements, enhance further research, provide information for technology reform and provide a basis for measuring impact (Yucel and Daalen, 2011).

Lagos State Agricultural Development Authority (LASADA), which was in charge of disseminating aquaculture and other agricultural related information to the farmers through its extension department/unit, has introduced many improved fisheries and aquaculture technologies to the fish farmers in Lagos State. Despite this, the promising nature of aquaculture through increased productivity has not been significantly noticed. This then calls for a need to assess what the real problem is likely to be. It is in that sense that this study assessed the level of adoption of improved aquaculture technologies among fish farmers in Lagos State. This provides researchers (National Research Institutes 
-NRIs and Universities) in this aspect with information on the improved aquaculture technologies that have been introduced through the fish farmers' awareness of each of the technologies. It also provides information on the technologies that were tried and adopted by the fish farmers as well as technologies that were mostly discontinued after initial adoption. The essence is to allow researchers and policy makers to know and plan on the technologies which are really working as expected and how those that were either rejected or discontinued due to underperformance could be improved and reintroduced to the fish farmers.

To ensure the aforementioned, the specific objectives of the study were to:

1. Describe the socio-economic characteristics of the fish farmers in Lagos State;

2. Identify the fish farming production characteristics of the fish farmers;

3. Investigate the access of fish farmers to extension services on fisheries technologies in Lagos State;

4. Describe the dynamic nature of the adoption of the different improved aquaculture technologies by the fish farmers; and

5. Ascertain the attitudes of fish farmers towards the adoption of improved aquaculture technologies in Lagos State.

The study also hypothesized that socio-economic and production characteristics of fish farmers are not significant predictors of adoption of improved aquaculture technologies by the fish farmers.

\section{METHODOLOGY}

\section{Study area}

Lagos State is located in the south-western part of Nigeria on the narrow coastal plain of the Bright of Benin and lies approximately on longitude $20^{\circ} 42^{\prime} \mathrm{E}$ and $3^{\circ} 22^{\prime} \mathrm{E}$, respectively, and between latitudes $6^{\circ} 22^{\prime} \mathrm{N}$. It is bounded to the north and east by Ogun State, to the west by the Republic of Benin and it stretches over 180 $\mathrm{km}$ along the bright of Benin on the Atlantic Ocean to the south. Its jurisdiction comprises the city of Lagos and five administrative divisions of Ikeja, Lagos Island, Ikorodu, Epe and Badagry. It covers a total land area of $4.000 \mathrm{~km}^{2}$, out of which $30.0 \%$ is water. The State has a marine shoreline of about $180 \mathrm{~km}$ and extends inland for about $32 \mathrm{~km}$ (at its farthest points) from the shoreline. The State is rich in water resources for fishing and other aquatic activities. Annual rainfall varies from $1.312 \mathrm{~mm}$ to $1.726 \mathrm{~mm}$ with two seasonal rainfalls that last between April and November. Average minimum temperature ranges from $19^{\circ}-25^{\circ} \mathrm{C}$ with the maximum of $27^{\circ}-37^{\circ} \mathrm{C}$. Relative humidity is about $60.0 \%$ throughout the year. Due to the availability of water resources, fishing has become one of the major occupations of the residents of Lagos State, especially those in riverine fishing communities.

Other agriculture-related occupations in the State include, but are not limited to, crop production, poultry keeping, rabbit rearing, swine breeding and rearing. The State was divided into three Agricultural Development Project (ADP) operational zones (east, far east and west), covering all the twenty LGAs to ensure that extension activities reach more fish farmers and fisherfolk statewide. For the purpose of administrative convenience, the three zones were further stratified into sixteen extension blocks and each block was headed and managed by Block Extension Supervisor (BES); Block Extension Agent (BEA) worked with Women in Agriculture (WIA) at group level, while the Village Extension Agents (VEAs) worked with farm families at 128 circle levels (villages). The population for this study was all fish farmers from Lagos State, Nigeria.

\section{Sampling procedure and sample size}

The study adopted the multistage sampling technique which comprises both the probability and non-probability sampling techniques. The Stage 1 entailed the random sampling of $50.0 \%$ of the extension blocks in each of the 3 ADP operational zones in the State. This resulted in the selection of 8 out of 16 extension blocks. Stage 2 involves the purposive selection of 4 circles, each from the selected extension blocks. The first four circles in terms of the population of fish farmers in each of the extension blocks (based on suggestions of LASADA personnel) were chosen and this resulted in 32 circles. The final stage then involved the convenient sampling of any 3 fish farmers in the selected circles since there was no comprehensive list of fish farmers in different circles. This resulted in a total of 96 fish farmers but only 90 of these were able to assist in responding completely and accurately to the interview schedule used for this study.

\section{Data collection instrument and data analysis}

The instrument used for the gathering of primary data used in this study was a validated and pre-tested interview schedule. This is because not all the fish farmers were literate enough to fill out a questionnaire by themselves. The interview schedule consists of different sections with respect to the specific objectives of the study. The interview schedule was found to be both valid and reliable through the face and content validity, and test-re-test reliability techniques, respectively.

Collected data were coded and entered into the Statistical Package for Social Sciences version 17.0. Descriptive statistics (frequency, mean and standard deviation) was used to analyse the specific objectives of the study, while the tested hypothesis was analysed with regression analysis. 


\section{RESULTS AND DISCUSSION}

\section{Socio-economic characteristics of fish farmers in Lagos State}

Table 1 reveals that about half of the fish farmers were aged between 41 and 50 years. About 23 out of 90 fish farmers were between 31 and 40 years old, while only 14 and 5 of the fish farmers were aged 51-60 years and older than 60 years, respectively. When pooled together, almost all fish farmers were between 21 and 60 years old. Furthermore, the mean age of the farmers was found to be $45.14 \pm 8.45$ years which implies that the majority of the fish farmers were among the active, productive and working population of the nation. This is in line with the categorization of Ande (2008) which placed persons between 16 and 60 years into the working population of a nation. Due to the adventurous nature of persons that fall in this category, the fish farmers are likely to adopt improved technologies that have been proven or have the potential to lead to increased income and improved productivity.

As also shown in Table 1, the majority of the fish farmers were males, while only 15 out of the 90 fish farmers were females. This is an indication that fish farming in Lagos State is highly dominated by men. The dominance of male in fish farming in Lagos State was also reported by Omitoyin and Tosan (2012). The possible reason for male dominance in fish farming is attributed to the tedious and energy-sapping nature of fish farming which most women may not be able to cope with. The involvement of some women in this enterprise is also an indication that women are no longer sitting back at home waiting to do the processing, marketing and cooking of the fishes; they now also go into fishing as men do. The implication is then that improved technologies that do not take women into consideration may not receive acceptance especially from the woman fisherfolk.

Almost all the sampled fish farmers in Lagos State were shown in Table 1 to be married, while the remaining were either widowed ( 3 out of 90 ), separated or divorced ( 2 out of 90 ), or never married ( 1 out of 90 ). This implies that marriage was highly cherished by the sampled fish farmers in the study area and this is in agreement with the findings of Baruwa et al. (2012) who reported $94.7 \%$ of the fish farmers in Lagos State to be married. This is likely to influence fish farmers' decisions on the need to adopt improved aquaculture technologies because marriage places family responsibilities on them and for these responsibilities to be continually met, increase in their income and improvement of their productivity will be highly appreciated by the fish farmers. The introduction of improved aquaculture technologies is therefore a good step taken by the extension workers in the right direction to the fish farmers. About 57 and 28 of the fish farmers claimed to practice Christianity and Islam, respectively, while only 5 out of 90 fish farmers practiced traditional religions. This implies that the majority of the fish farmers in the study area either practiced Christianity or Islam and that the traditional means of worship are no longer as popular as in the olden days.

The study further reveals that more than three-quarters of the fish farmers were of the Yoruba ethnic group, 15 of the fish farmers constituted the Eguns, while the remaining ( 6 out of 90 ) belonged to the Hausa, Ibo, Ijaw and Isoko ethnic groups. This implies that ethnic groups other than the Yorubas (who primarily dominate the State) were also found in Lagos State and peacefully engaging in business activities such as fish farming. This supports the earlier findings of Omitoyin and Tosan (2012) who reported the participation of ethnic groups such as Egun, Ibo, Ijaw, Hausa, Ilaje and Isoko in fish farming in Lagos State. The indication of this is that the migrants from other states within the country are likely to adopt improved technologies faster and also influence the host farmers in the adoption of such technologies due to their exposure. In terms of educational attainment, the result in Table 1 reveals that only 8 out of the 90 fish farmers had no formal education with the highest proportion (37 out of 90) having the elementary/primary education. Only about 25 and 20 out of the 90 fish farmers continued up to secondary and tertiary education, respectively. This implies that at least half of the fish farmers had the basic education, recommended and made compulsory by the federal government of Nigeria. With this educational attainment, the adoption of improved aquaculture technologies could be facilitated as education plays a significant role in the adoption of technologies.

Close to two-thirds of the fish farmers had been in fish farming business for 1-5 years, while 19 and 15 of the fish farmers had been into fish farming business for 6-10 and $>10$ years, respectively. The mean fish farming experience of $5.72 \pm 2.12$ years indicated that the fish farmers had not been in the business for a very long time and hence may tend to adopt aquaculture technologies that tend to improve their productivity, as opposed to those who had been in the business for a long time. Furthermore, Table 1 shows that more than half of the fish farmers were working as full-time fish farmers. Aside from fish farming, close to two-thirds of the fish farmers took farming as secondary occupation. The choice of farming as secondary occupation by most of the fish farmers was also reported by Omitoyin and Tosan (2012) who reported the secondary occupation of fish farmers to be primarily crop production, especially during the dry season. Other secondary occupations of the fish farmers are trading and artisanal/vocational jobs, while about 12 out of the 90 fish farmers did nothing aside from fish farming. This implies that the majority of the fish farmers have diversified income sources and as such were well equipped in cases of risk factors that may affect fish farming.

Also, 52 out of the 90 fish farmers belonged to one fish farmers association/cooperative society or the other, and this corroborates Olaoye et al. (2013) who reported that close to two-thirds of the fish farmers were members of 
Table 1. Socio-economic characteristics of fish farmers in Lagos State

\begin{tabular}{|c|c|c|}
\hline Socio-economic characteristics & Frequency & Mean $\pm S D$ \\
\hline \multicolumn{3}{|l|}{ Age (Years) } \\
\hline $21-30$ & 2 & \\
\hline $31-40$ & 23 & $45.14 \pm 8.45$ \\
\hline $41-50$ & 46 & \\
\hline $51-60$ & 14 & \\
\hline$>60$ & 5 & \\
\hline \multicolumn{3}{|l|}{ Sex } \\
\hline Male & 75 & \\
\hline Female & 15 & \\
\hline \multicolumn{3}{|l|}{ Marital status } \\
\hline Single & 1 & \\
\hline Married & 84 & \\
\hline Widowed & 3 & \\
\hline Divorced (Separated) & 2 & \\
\hline \multicolumn{3}{|l|}{ Religion } \\
\hline Islam & 28 & \\
\hline Christianity & 57 & \\
\hline Traditional & 5 & \\
\hline \multicolumn{3}{|l|}{ Ethnicity } \\
\hline Egun & 15 & \\
\hline Yoruba & 69 & \\
\hline Others (Hausa/Ibo/Ijaw/Isoko) & 6 & \\
\hline \multicolumn{3}{|l|}{ Highest educational attainment } \\
\hline No formal education & 8 & \\
\hline Elementary/primary education & 37 & \\
\hline Secondary education & 25 & \\
\hline Tertiary education & 20 & \\
\hline \multicolumn{3}{|l|}{ Fish Training } \\
\hline Acquired & 38 & \\
\hline Not acquired & 52 & \\
\hline \multicolumn{3}{|l|}{ Fish farming experience (Years) } \\
\hline $1-5$ & 56 & \\
\hline $6-10$ & 19 & $5.72 \pm 2.12$ \\
\hline$>10$ & 15 & \\
\hline \multicolumn{3}{|l|}{ Mode of fishing } \\
\hline Part time & 42 & \\
\hline Full time & 48 & \\
\hline \multicolumn{3}{|l|}{ Secondary occupation } \\
\hline Trading & 9 & \\
\hline Farming & 59 & \\
\hline Artisan/vocational & 10 & \\
\hline None & 12 & \\
\hline \multicolumn{3}{|c|}{ Membership of fish farmers' association/cooperative } \\
\hline Members & 52 & \\
\hline Non-members & 38 & \\
\hline \multicolumn{3}{|l|}{ Available infrastructures* } \\
\hline Schools & 62 & \\
\hline Hospital/maternity home/health centers & 35 & \\
\hline Banks & 11 & \\
\hline Markets & 60 & \\
\hline Perennial water source & 38 & \\
\hline Reputable hatcheries & 14 & \\
\hline
\end{tabular}

Source: Field survey, 2014 *multiple responses used 
cooperative societies. This implies that adoption of improved technologies could be easily facilitated to this group of fish farmers because it can be easier to demonstrate the technologies to a group than to an individual. Schools were available to more than two-thirds of the fish farmers. Also, markets were made readily available to 60 out of the 90 fish farmers. Other infrastructures like healthcare centers, banks, perennial water source and reputable hatcheries were not available to most of the fish farmers in Lagos state. This explains why most of the fish farmers could not take fish farming as a full time enterprise as, for instance, there will be a need for alternative water sources during the dry season. Also, the absence of available banks to most of these fish farmers prevents them from going into large-scale fish farming and therefore limits their adoption of improved technologies that may involve huge amount of capital.

\section{Marketing characteristics and fish farmers' access to credit facilities}

About 80 out of the 90 fish farmers sold their fishes as smoked fish. However, only about one-third of the fish farmers sold theirs as fresh fish while very few $(21,14$ and 2 out of the 90 fish farmers) sold fishes as frozen fish, dried fish and fish meals, respectively. This implies that the fish farmers prefer to sell their fishes after adding value to their catches through smoking. This may explain why such a good profit is still made despite their low investment.

Table 2 further reveals that 64 out of the 90 fish farmers marketed or sold their fishes at local fish markets. Other sites used for marketing fish were processing sites and urban markets which were used by 31 and 28 out of the 90 fish farmers, respectively. This implies that local fish markets are the most commonly used means of marketing fishes by the fish farmers. It also indicated that different channels were used by the fish farmers in marketing their produce. Table 2 also shows that fishes were sold by 71 out of the 90 fish farmers by considering the sizes of the fishes, while 55 out of 90 fish farmers made use of the hand method whereby fishes are sold in 200 pieces. Weighing scales were, however, used by 18 out of the 90 fish farmers in the study area. This implies that the fish farmers have been selling their produce based on the type of buyers they got as well as the circumstance in which the transaction took place. By doing so, a combination of different means was adopted by the fish farmers and there may be a need to raise awareness campaign on the use of a standard scale by the fish farmers. Furthermore, Table 2 shows that more than half of the fish farmers sourced credit facilities from cooperative societies which they belonged to, while Esusu was used by 30 out of the 90 fish farmers. Agricultural banks, local money lenders and non-governmental organizations (NGOs) serviced 11, 19 and 7 of the fish farmers with credit facilities, respectively. However, only 2 out of 90 fish farmers made use of their personal savings. This implies that the majority of the fish farmers only made use of the informal means to get credit facilities for their fish farming enterprise and this is in line with the submission of Baruwa et al., 2012 who noted that more than three-quarters of the fish farmers in their study relied heavily on the informal sources of credit such as personal savings and credits sourced from friends and relatives. Adeshinwa and Bolorunduro (2007) also reported that personal savings, cooperative societies and friends were main sources of financing fish farming in Lagos State. The majority of the fish farmers took a loan higher than N20.000, while 14 and 12 out of the 90 fish farmers borrowed $\mathrm{N} 15.001-\mathrm{N} 20.000$ and $\mathrm{N} 1,001-\mathrm{N} 15,000$, respectively. The mean amount of credits obtained by the fish farmers was calculated at $\mathrm{N} 24.3222 \pm 4561.25$ to be repaid with interests over a period of time. This also explains that the fish farmers do not have access to larger

Table 2. Marketing characteristics and fish farmers' access to credit facilities

\begin{tabular}{|c|c|c|}
\hline Economic characteristics & Frequency & Mean \pm SD \\
\hline \multicolumn{3}{|l|}{ Form of selling fish* } \\
\hline Fresh & 34 & \\
\hline Frozen fish & 21 & \\
\hline Smoked fish & 80 & \\
\hline Dried fish & 14 & \\
\hline Fish meals & 2 & \\
\hline \multicolumn{3}{|l|}{ Site of fish marketing* } \\
\hline Processing sites & 31 & \\
\hline Local fish markets & 64 & \\
\hline Urban markets & 28 & \\
\hline \multicolumn{3}{|c|}{ Form/manner of marketing fish* } \\
\hline Weighing scale (Kg) & 18 & \\
\hline Hand (200 pieces) & 55 & \\
\hline Sizes & 71 & \\
\hline \multicolumn{3}{|l|}{ Sources of credit* } \\
\hline Agricultural banks & 11 & \\
\hline Cooperative societies & 50 & \\
\hline Local money lenders & 19 & \\
\hline NGO & 7 & \\
\hline Esusu & 30 & \\
\hline Personal savings & 2 & \\
\hline \multicolumn{3}{|c|}{ Amount of credits obtained (Naira) } \\
\hline $1000-5000$ & 5 & \\
\hline $6001-10000$ & 3 & $24322.22 \pm 4561.25$ \\
\hline $10001-15000$ & 3 & \\
\hline $15001-20000$ & 14 & \\
\hline$>20000$ & 63 & \\
\hline \multicolumn{3}{|l|}{ Interest rates (\%) } \\
\hline$\leq 10$ & 70 & $9.14 \pm 1.12 \%$ \\
\hline $11-20$ & 18 & \\
\hline \multicolumn{3}{|l|}{ Payback period (months) } \\
\hline 6 & 7 & \\
\hline 12 & 68 & $12.93 \pm 2.34$ \\
\hline 24 & 8 & \\
\hline 36 & 5 & \\
\hline
\end{tabular}

Source: Field survey, $2014 *$ multiple responses used, $1 £=$ N282.28 
amount of credits due to their subsistence nature. Table 2 further reveals that 70 out of the fish farmers took loans that have interest rates of $10.0 \%$ or less while only 18 of them borrowed at an interest rate higher than $10.0 \%$. The mean interest rate associated with loans taken by sampled fish farmers was calculated at $9.14 \pm 1.12 \%$. This implies that although the informal financial institution was mostly used by the fish farmers, the interest rate is still affordable to the majority of the fish farmers.

The payback period for loans taken by the majority of the fish farmers was 12 months ( 1 year). Seven of the fish farmers usually pay back in 6 months, while 8 and 5 of the fish farmers paid back their loans in 2 and 3 years, respectively. The mean payback for the fish farmers was calculated at $12.93 \pm 2.34$ month which is expected to allow the fish farmers to have operated at least one production cycle and so be able to repay their loans.

\section{Costs and returns from fish production}

Table 3 also shows that more than half of the fish farmers produced more than $100.0 \mathrm{~kg}$ while about 34 out of the 90 fish farmers produced between $10.1 \mathrm{~kg}$ and $100.0 \mathrm{~kg}$ per annum. The mean fish output of the fish farmers was found to be $85.19 \pm 9.50 \mathrm{~kg}$, which is relatively low. This low output is a result of the use of subsistence fish farming techniques. About 76 of the fish farmers sold fishes at $\mathbf{N} 201-500$ per $\mathrm{kg}$ while 13 and 1 of the 90 fish farmers sold the fishes at $\mathrm{N} 100$ 200 and $>\mathbb{N 5 0 0}$, respectively. The mean selling price of the

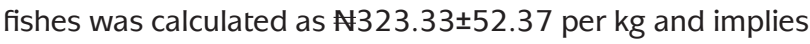
that the price of fish per $\mathrm{kg}$ is relatively cheap among the fish farmers. The cheap selling price of fish is attributed to the categories of consumer that patronized the fish farmers. As revealed in Table 3, close to half of the fish farmers and about one-quarter spent over $\mathrm{N50.000}$ and $\mathrm{N21.000-}$ 30.000 , respectively, on pond construction, while 12 out of the 90 fish farmers spent $\mathrm{N} 31.000-40.000$ on pond construction. The mean amount expended by the fish farmers

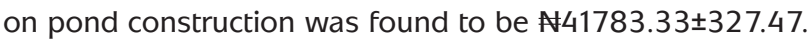
The average cost of managing ponds by the fish farmers was $\mathrm{N} 27,866.67 \pm 2,435.00$ while the cost of fingerlings stocked was $\mathrm{N} 32,277.78 \pm 2,450.45$. Close to half of the fish farmers were also reported in Table 3 to have earned more than N50,000 as profit per annum, while 20 of the fish farmers earned a profit of between $\mathbf{N 4 1 , 0 0 0}$ and $\mathbf{N 5 0 , 0 0 0}$ on an annual basis. The mean annual profit for the fish farmers in Lagos State was $\$ 43,655.56 \pm 1,725.29$. When compared to the fish farmers' investments in terms of costs of pond construction, pond management and stocking of fingerlings, the profit realized seems to be good enough. However, the profit could be increased if more investment is made through the adoption of improved aquaculture technologies. Table 3 further reveals that 40 out of the 90 sampled fish farmers earned more than $\mathrm{N50,000}$ as income on an annual basis, while 24 of the fish farmers earned between $\mathbf{A 4 0 , 0 0 1}$

and $\mathbf{N 5 0 , 0 0 0}$ as annual income. The mean annual income of the fish farmers was found to be $N 42,111.11 \pm 2,215.46$, which is less than $\mathbf{N 4 , 0 0 0}$ on a monthly basis. This is an indication that the fish farmers are small-scale farmers making use of the subsistence ways of going through their business activities. Hence, they need to adopt improved aquaculture technologies that could increase their income through improved productivity and cost-effectiveness which characterized the improved technologies.

Table 3. Costs and returns of fish farming in Lagos State $(n=90)$

\begin{tabular}{lcc}
\hline \hline Costs and Return variables & Frequency & Mean \pm SD \\
\hline Fish output $(\mathrm{Kg})$ & & \\
$\leq 5$ & 5 & $85.19 \pm 9.50$ \\
$5.1-10.0$ & 3 & \\
$10.1-100$ & 34 & \\
$>100$ & 48 &
\end{tabular}

\section{Fish price/Kg (Naira)}

100-200

$323.33 \pm 52.37$

201-500

13

$>500$

Cost of pond construction (Naira)

$10000-20000$

21000-30000

$41,783.33 \pm 327.47$

31000-40000

41000-50000

12

7

$>50000$

Cost of pond management (Naira)

$<10000$

10000-20000

21000-30000

31000-40000

41000-50000

$>50000$

43

Cost of fingerlings stocked (Naira)

$<10000$

10000-20000

21000-30000

31000-40000

41000-50000

$>50000$

Profit from fisheries activities (Naira) $<10000$

10000-20000

21000-30000

31000-40000

41000-50000

$>50000$

\section{Annual income (Naira)}

$\leq 10000$

10001-20000

20001-30000

30001-40000

40001-50000

$>50000$

Source: Field survey, 2014; $1 £=\$ 282.28$
$27,866.67 \pm 2,435.00$

18

12

6

18

$32,277.78 \pm 2,450.45$

6

15

19

19

4

4

13

5

20

44

$43,655.56 \pm 1725.29$

$42,111.11 \pm 2,215.46$ 


\section{Awareness and perceived effectiveness of extension services by fish farmers in Lagos State}

As presented in Table 4, the study revealed that all fish farmers were aware of the presence of extension workers in the study area. The majority of the fish farmers were visited on a forthnight basis. About 22 out of the 90 fish farmers were visited by extension workers on monthly basis while 2 out of the 90 fish farmers were visited by extension workers on an irregular basis. The difference in the periods of visit of extension workers to fish farmers' farms is a reflection of many factors which include distance of fish farming communities to extension offices, fish farmers' farm schedule and availability of adequate number of extension workers to visit the farms, amongst others. The implication of the findings of this study is that fish farmers will get information about improved technologies at different rates and this further implies that the adoption or rejection of technologies will be varied by the period of visit of extension workers to fish farmers, among other things.

The rating of fish farmers' contact with extension agents presented in Table 4 reveals that 34 and 52 of the fish farmers were visited on very regular and regular bases, respectively, while only 4 of them were visited on an irregular basis. This implies that although fish farmers were visited more on forthnight and monthly bases, the visits were still perceived to be regular by the majority of the fish farmers, which indicated that there has been consistency in the dissemination and demonstration of improved technologies to the fish farmers. This is expected to facilitate the fish farmers' adoption of improved aquaculture technologies that were introduced to the fish farmers. The teaching ability of the extension agents on the issues related to fisheries was rated by more than half of the fish farmers as very good, while 43 rated it as good, with one of the fish farmers considering extension agents' teaching ability as poor. This is in conformity with the perception of the fish farmers who described extension agents as being punctual, energetic, cheerful, able to carry people along, able to demonstrate technologies and proffer solution to problems (Agbebi, 2012). This is an indication that the extension agents were able to effectively discharge their responsibilities through teaching and demonstration.

As shown in Table 4, at least one improved aquaculture technology has been demonstrated to 87 of the fish farmers while 85 out of the 90 fish farmers believed that the demonstrated technologies have been useful in their fish farming enterprise. Table 4 further reveals that the usefulness of the demonstrated technologies were found in terms of increased income, compatibility with existing practices and better comparative advantages by 85,83 and 84 of the fish farmers, respectively. This is an indication that almost all fish farmers benefited in one way or the other from the demonstrated technologies. The effectiveness of extension service was also reported by Adeshinwa and Bolorunduro (2007) through small plot adoption trial (SPAT), field day, method demonstration, agric show and result demonstration. Furthermore, Table 4 also

Table 4. Awareness and perceived effectiveness of extension services by fish farmers in Lagos State $(n=90)$

\begin{tabular}{|c|c|}
\hline Extension service variables & Frequency \\
\hline \multicolumn{2}{|l|}{ Awareness of extension agents } \\
\hline Aware & 90 \\
\hline \multicolumn{2}{|c|}{ Period of Extension Agent's visit } \\
\hline Forthnightly & 66 \\
\hline Monthly & 22 \\
\hline Quarterly & 0 \\
\hline Not regularly & 2 \\
\hline \multicolumn{2}{|l|}{ Extension Agent's contact } \\
\hline Very regular & 34 \\
\hline Regular & 52 \\
\hline Not regular & 4 \\
\hline \multicolumn{2}{|c|}{ Extent of extension agent's teaching ability } \\
\hline Very good & 46 \\
\hline Good & 43 \\
\hline Poor & 1 \\
\hline \multicolumn{2}{|c|}{ Demonstrated fisheries technology? } \\
\hline Yes & 87 \\
\hline \multicolumn{2}{|c|}{ Usefulness of demonstrated technologies } \\
\hline Useful & 85 \\
\hline Not useful & 5 \\
\hline \multicolumn{2}{|c|}{ Demonstrated technologies improved income } \\
\hline Yes & 85 \\
\hline \multicolumn{2}{|c|}{$\begin{array}{l}\text { Compatibility of demonstrated technologies with } \\
\text { existing practice }\end{array}$} \\
\hline Yes & 83 \\
\hline \multicolumn{2}{|c|}{ Better comparative advantages of technologies } \\
\hline Yes & 84 \\
\hline \multicolumn{2}{|c|}{ Sources of information on fisheries* } \\
\hline Extension agent & 85 \\
\hline Other farmers & 34 \\
\hline Radio & 52 \\
\hline Television & 52 \\
\hline \multicolumn{2}{|c|}{ Assessment of extension service } \\
\hline Very Good & 39 \\
\hline Good & 42 \\
\hline Fair & 7 \\
\hline Very Poor & 0 \\
\hline \multicolumn{2}{|c|}{ Characteristic of extension service* } \\
\hline Easy to understand & 88 \\
\hline Easy to implement & 72 \\
\hline \multicolumn{2}{|c|}{$\begin{array}{l}\text { Degree of extension agents' interest in the } \\
\text { welfare of small-scale fishers }\end{array}$} \\
\hline Highly interested & 58 \\
\hline Interested & 29 \\
\hline Slightly interested & 3 \\
\hline Not interested & 0 \\
\hline
\end{tabular}

Source: Field survey, $2014 *$ multiple responses used 
shows that the majority of the fish farmers were aware of fisheries technologies through the extension agents. This is because extension workers have been to most of the fishing communities to disseminate innovations that could improve aquaculture productivity.

This corroborates the findings of Olaoye et al. (2014) who reported that information on fish farming was regularly sourced from extension agents by about two-thirds of the fish farmers. More than half of the fish farmers also sourced information on fisheries technologies from radio and television broadcasting. In addition, fellow fish farmers served as means of awareness of fisheries-related information to $37.8 \%$ of the fish farmers. This implies that information on improved aquaculture technologies and other farming related practices were disseminated to fish farmers through different sources such as face-to-face contact and broadcasting media.

Eighty-one out of the ninety fish farmers assessed the extension services provided by extension workers on the dissemination and demonstration of improved aquaculture technologies as either very good (39) or good (42). Only 7 of the fish farmers rated them as fair while no one rated the extension services as poor. This shows that extension services provided by the extension workers were satisfactory to the fish farmers and that they will enhance the fish farmers' adoption of improved aquaculture technologies. To this end, the extension services were characterized as easy to understand and easy to implement by 88 and 72 of the fish farmers, respectively. Close to two-thirds of the fish farmers also perceived that the extension agents were highly interested in the fish farmers' affairs while about one-third also perceived them as just interested in the fish farmers' affairs. This explains why the extension agents' teaching ability and extension services with respect to fish farming were highly rated by the fish farmers.

Different types of fish enclosure, neutralizers, fertilizers and fish stock selectivity technologies were disseminated by extension agents to the fish farmers in the study area. Below is the result of the adoption of different improved aquaculture technologies by the fish farmers at different rates.

As seen in Table 5, this study shows that all fish farmers were aware, tried and adopted the dugout (earthen) fish pond. However, about 9 of the fish farmers discontinued the use of dugout (earthen) fish pond. Also, Table 5 shows that all fish farmers were aware of the barrage (embankment) fish pond. Out of this, 82 and 80 tried and adopted the fish enclosure technology, respectively. But out of the 80 fish farmers that adopted the embankment fish pond, up to 60 fish farmers discontinued the use of the technology after its adoption. Table 5 also reveals that 87 of the fish farmers were aware of the paddy (rice field) fish pond, while 84 fish farmers went to the trial stage. After the trial stage, only 3 of the fish farmers adopted it as a fish enclosure technology. Unfortunately, the 3 fish farmers who adopted the technology also discontinued its use after some time. As for the tidal pond, only 30 out of the 90 fish farmers were aware of it as a fish enclosure technology. Only 3 of the fish farmers tried the technology while none of the fish farmers adopted the tidal pond as a fish enclosure technology. As for the raceway pond, about 31 of the fish farmers were aware of it as a fish enclosure technology and only about 6 of them went forward to the trial stage of adopting this technology. At last 5 of the fish farmers adopted the technology with no one discontinuing its use as a viable fish enclosure technology.

All fish farmers were aware, tried and adopted the use of weir ponds as a fish enclosure technology. It is, however, unfortunate that all those that adopted the technology discontinued its use after some time. About 30 out of the 90 fish farmers were aware of the use of fish beels as fish enclosures and only 8 of the fish farmers tried and adopted the use of the technology. However, 6 out of the 8 fish farmers that adopted the technology discontinued its use after some time. Table 5 also shows that while all the fish farmers were aware, tried and adopted the use of a fish tank, 7 fish farmers discontinued its use after some time. This may be attributed to land ownership issues as most of the fish farmers do not own sufficient land of their own. The adoption of earthen ponds as fish enclosure by more than half of the beneficiaries of Fadama II was also reported by Tiamiyu et al. (2015).

About 78 of the fish farmers were aware of the use of fish trough as fish enclosure technology and of these 59 and 58 of the fish farmers tried and adopted fish trough, respectively. Surprisingly, more than half (35 out of 58 ) of those that adopted the technology, discontinued its use. As for fish tub, results in Table 5 reveal that a little more than half of the fish farmers were aware of it as a fish enclosure technology. But only 3 out of 50 fish farmers tried and adopted the technology. The fish tub was, however, discontinued by all those that previously adopted it as a fish enclosure. The awareness of fish cages was high among the fish farmers as 82 of the fish farmers were aware of it. Also, Table 5 shows that 64 of the fish farmers tried and adopted the use of fish cages as fish enclosure. However, 41 out the 64 fish farmers that adopted the technology discontinued its use over time. Up to 76 out of the 90 fish farmers were aware of fish pens as fish enclosure. About 56 out of 76 fish farmers tried while 48 fish farmers finally adopted the use of fish pens as fish enclosure. Unfortunately, 20 out of the 48 fish farmers who adopted the technology also discontinued its use after some time.

With respect to fish creel, Table 5 reveals that less than half of the fish farmers were aware of its use as fish enclosure. It is surprising to find that only 2 of the fish farmers tried and adopted fish creels. It is more surprising to note that the 2 fish farmers also discontinued its use and fish creel is not currently in use by the sampled fish farmers in the study area. Table 5 shows that close to three-quarters of the fish 
Table 5. Distribution of the level of adoption of improved aquaculture technologies by fish farmers in Lagos State $(n=90)$

\begin{tabular}{|c|c|c|c|c|}
\hline Improved aquaculture technologies & Awareness & Trial & Adopted & Discontinued \\
\hline \multicolumn{5}{|l|}{ Fish enclosures } \\
\hline Dug out (earthen) fish pond & 90 & 90 & 90 & 10 \\
\hline Barrage (embankment) fish pond & 90 & 82 & 80 & 60 \\
\hline Paddy (rice field) fish pond & 87 & 84 & 3 & 3 \\
\hline Tidal Pond & 30 & 3 & 0 & 0 \\
\hline Raceway ponds & 31 & 6 & 5 & 0 \\
\hline Weir ponds & 90 & 90 & 90 & 90 \\
\hline Fish beels & 30 & 9 & 9 & 6 \\
\hline Fish tanks & 90 & 90 & 90 & 7 \\
\hline Fish trough & 77 & 59 & 58 & 32 \\
\hline Fish tub & 50 & 3 & 3 & 3 \\
\hline Fish cages & 82 & 64 & 64 & 37 \\
\hline Fish pen & 76 & 56 & 48 & 22 \\
\hline Fish creel & 38 & 2 & 2 & 2 \\
\hline Fish pot & 65 & 38 & 38 & 37 \\
\hline \multicolumn{5}{|l|}{ Neutralizers } \\
\hline Lime $\left(\mathrm{CaOH}, \mathrm{CaO}, \mathrm{CaCO}_{3}\right)$ & 90 & 86 & 77 & 7 \\
\hline Wood ash & 84 & 77 & 75 & 23 \\
\hline Carbide wastes & 60 & 50 & 50 & 45 \\
\hline \multicolumn{5}{|l|}{ Fertilizers } \\
\hline Cow - dung & 88 & 84 & 82 & 22 \\
\hline Poultry waste & 88 & 88 & 88 & 16 \\
\hline Pig dung & 82 & 51 & 46 & 25 \\
\hline Horse waste & 57 & 15 & 14 & 3 \\
\hline Putrefied vegetable residues (compost/silage) & 75 & 70 & 50 & 16 \\
\hline Midden residues & 29 & 2 & 1 & 0 \\
\hline Abattoir wastes & 73 & 69 & 69 & 23 \\
\hline Inorganic Fertilizers (N.P.K, Urea) & 90 & 90 & 90 & 85 \\
\hline Basic Slag $\left(\mathrm{CaCO}_{3}+\mathrm{P}\right)$ & 29 & 29 & 24 & 24 \\
\hline ‘Dacao' & 23 & 5 & 0 & 0 \\
\hline \multicolumn{5}{|l|}{ Fish stock selectivity } \\
\hline Fish fry & 90 & 90 & 90 & 84 \\
\hline Fish fingerlings & 90 & 90 & 90 & 0 \\
\hline Fish juvenile & 90 & 86 & 86 & 9 \\
\hline Fish sub-adult & 86 & 81 & 80 & 76 \\
\hline
\end{tabular}

Source: Field survey, 2014

farmers were aware of the use of fish pots as fish enclosure but only about 42 of the fish farmers tried and adopted the technology. Also, almost all (37 out of 42) fish farmers who adopted its use later discontinued after using fish pots for a period of time. It can be deduced that although the majority of fish farmers were aware, tried and adopted most of the fish enclosure technologies, discontinuation was also high in most of the fish enclosures. When the rate of adoption is compared with that of discontinuation, fish tanks and dug out (earthen) ponds remained the most commonly used fish enclosure technologies in the study area. This is in conformity with the submission of Idowu (2013) who positioned that 
fish tanks and earthen/dug-out fish ponds are the most commonly used fish enclosures in Nigeria. Olaoye et al. (2014) also noted that more than two-thirds of the fish farmers were making use of earthen ponds while concrete tanks and plastic tanks were in use by very few fish farmers. The implication is that adopting a technology for trial does not mean continuous use of the same technology as technologies could be discontinued if found not to meet expectations for which they were adopted. It also implies that adoption of improved technologies is dynamic over time and varies among people.

Neutralizers: Table 5 shows that all fish farmers were aware of the use of lime as a neutralizer. The majority (86 and 77) of the 90 fish farmers tried and adopted the use of lime, respectively, with only about 7 fish farmers discontinuing the use of lime after previous adoption. Furthermore, about 77 and 75 of the fish farmers tried and adopted the use of wood ash, respectively. However, about one-quarter of the fish farmers discontinued its use after adoption. Table 5 further reveals that 61 out of the 90 fish farmers were aware of the use of carbide waste. About 50 of the fish farmers went further to the trial and adoption stages. However, almost all of those that adopted the use of carbide waste ( 45 fish farmers) also discontinued its use after some time. The implication is that lime is the only neutralizer that was highly adopted by the majority of the fish farmers and also received the least discontinuation rate and thereby is the most commonly used neutralizer by sampled fish farmers. Wood ash is also still in use by more than half (52) of the fish farmers. The use of wood ash is attributed to its effectiveness, ease of use and local availability at minimal cost to farmers (Kudoro, 2013).

Fertilizers: Table 5 reveals that almost all fish farmers were aware that cow dung could be used as fertilizer on their fish farms. About 84 and 82 out of the 90 fish farmers tried and adopted its use, respectively. However, about 20 of those that adopted the use of cow dung as fish fertilizer, discontinued its usage after some time of adoption. This may be due to the fact that cow dungs harbour lots of pathogens and diseases that could be dangerous to the health of fishes. Almost all (88 out of 90) fish farmers were aware, tried and adopted the use of poultry waste as fish fertilizers with only about 16 fish farmers discontinuing its use after adoption. As for pig dung, 82 and 51 out of the 90 fish farmers were aware and tried its use, respectively. To this end, about half (46) of the fish farmers adopted the use of pig dung but more than half (25) of those who adopted pig dung also discontinued its use.

Furthermore, Table 5 shows that close to two-thirds (57) of the fish farmers were aware of the use of horse waste while only 14 tried and adopted the use of horse waste as fertilizer on their fish farms. Horse waste was, however, discontinued by 3 of the fish farmers after its adoption. The majority (75) of the fish farmers were aware of using compost/silage as fertilizers on their fish farms while 63 and 45 of the fish farmers tried and adopted its use. However, 16 of the fish farmers discontinued the use of compost/silage as fertilizer after its adoption. All fish farmers were also reported to be aware of inorganic fertilizer while 73 of the fish farmers were aware of abattoir wastes. The majority of the fish farmers also tried and adopted the two fertilizer types. However, almost all (85) fish farmers discontinued the use of inorganic fertilizers after their adoption. The implication is that fish farmers retained more the use of organic fertilizers than the use of inorganic fertilizers and this is attributed to the ready availability of wastes from livestock. This assertion is in line with the position of Kudoro (2013) who noted that fish farmers in rural areas make use of organic fertilizers due to their relative availability, abundance and their effectiveness in sustaining the green-coloured water for fish culture. This also explains why some of the organic fertilizers were discontinued as the livestock such as horses and pigs are not the common livestock in the study locations.

Fish stock selectivity: Table 5 shows that all fish farmers were aware, tried and adopted both fish fry and fish fingerlings. Although, no one discontinued the selection of fish fingerlings, up to 84 of the fish farmers discontinued the use of fish fry due to management problems and higher mortality issues. Fish juveniles and fish sub-adults were also popular among the fish farmers. The majority also adopted both fish stock selectivity, however, fish subadults were discontinued by 76 of the fish farmers and this may be attributed to cost implication. The continued use of fish fingerlings and fish juveniles by the majority of the fish farmers is in line with general recommendations of fish stocking. For instance, Kudoro (2013) emphasized that fish juveniles are highly recommended for stocking in ponds that already have some fishes, while fish fingerlings were recommended in a newly constructed pond devoid of any remnant fish, with fenced environment.

\section{Fish farmers' attitude towards adoption of improved aquaculture technologies}

Table 6 reveals that the majority of the fish farmers responded favourably to all attitudinal statements about the adoption of improved aquaculture technologies. Top on the list is the fact that large family size does not discourage farmers' use of improved fishery technologies. This is followed by the fact that improved fishery technologies save time and that the use of improved fishery technologies increases profits via increased yield. Also, the majority of the fish farmers disagreed with the fact that improved fisheries technology encourages laziness. 
Table 6. Fish farmers' attitude towards adoption of improved aquaculture technologies $(\mathrm{n}=90)$

\begin{tabular}{|c|c|c|c|c|c|c|c|}
\hline & Attitudinal statements & SA & A & U & D & SD & Mean \\
\hline 1 & Using improved fisheries technologies saves time & 21 & 9 & 0 & 1 & 59 & 4.58 \\
\hline 2 & $\begin{array}{l}\text { Improved fisheries technologies conserves farmers' energy } \\
\text { Human, material \& finance }\end{array}$ & 21 & 7 & 2 & 18 & 42 & 4.26 \\
\hline 3 & Lazy fish farmers use improved technologies & 0 & 0 & 3 & 33 & 54 & 4.50 \\
\hline 4 & $\begin{array}{l}\text { Using improved fisheries technologies lead to high product } \\
\text { losses }\end{array}$ & 3 & 1 & 34 & 21 & 31 & 3.84 \\
\hline 5 & $\begin{array}{l}\text { Large family size discourages fish farmers' use of improved } \\
\text { technologies }\end{array}$ & 0 & 4 & 3 & 18 & 65 & 4.60 \\
\hline 6 & $\begin{array}{l}\text { Fish farmers use of improved technologies increases profit/ } \\
\text { improved income via higher yield/harvest }\end{array}$ & 22 & 8 & 0 & 19 & 41 & 4.56 \\
\hline 7 & Improved fisheries technologies are not gender sensitive & 8 & 8 & 7 & 26 & 41 & 3.93 \\
\hline 8 & Using improved technologies help to reduce drudgery & 7 & 15 & 26 & 11 & 31 & 4.12 \\
\hline 9 & $\begin{array}{l}\text { Improved fisheries technologies improve the quantity and } \\
\text { quality of fish harvest }\end{array}$ & 25 & 5 & 0 & 4 & 56 & 4.48 \\
\hline 10 & $\begin{array}{l}\text { The improved technologies are easier to handle and } \\
\text { operate }\end{array}$ & 13 & 17 & 0 & 13 & 47 & 4.13 \\
\hline 11 & $\begin{array}{l}\text { Correct application of improved technologies requires } \\
\text { some training }\end{array}$ & 14 & 16 & 0 & 9 & 51 & 3.74 \\
\hline 12 & $\begin{array}{l}\text { Skills required for the use of the improved technologies can } \\
\text { be easily acquired }\end{array}$ & 9 & 13 & 32 & 8 & 28 & 3.76 \\
\hline 13 & $\begin{array}{l}\text { Adopting the improved technologies gives me a sense of } \\
\text { satisfaction }\end{array}$ & 14 & 15 & 1 & 3 & 57 & 4.29 \\
\hline 14 & $\begin{array}{l}\text { Improved technologies fit well into existing fisheries } \\
\text { systems }\end{array}$ & 9 & 20 & 1 & 12 & 48 & 4.28 \\
\hline 15 & $\begin{array}{l}\text { Improved fisheries technologies may involve consistence or } \\
\text { otherwise discontinuance }\end{array}$ & 8 & 12 & 4 & 18 & 48 & 4.06 \\
\hline 16 & $\begin{array}{l}\text { Government policy changes have positive impact on } \\
\text { adoption and discontinuance of improved fisheries } \\
\text { technologies }\end{array}$ & 6 & 6 & 32 & 15 & 31 & 3.93 \\
\hline
\end{tabular}

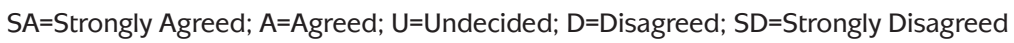

Relationship between socio-economic and production characteristics of the fish farmers and their adoption of improved aquaculture technologies

Table 7 reveals that fish farmers' adoption of improved aquaculture technologies is significantly predicted by their secondary occupation $(\beta=-0.324, p<0.01)$, annual income level $(\beta=-0.471, p<0.05)$, cost of pond construction $(\beta=0.477, p<0.05)$ and total profit realized $(\beta=-0.466$, $p<0.05)$. The $R^{2}$ of 0.460 for the model implies that $46.0 \%$ of the variability in the fish farmers' adoption of improved aquaculture technologies is explained by the socioeconomic characteristics of the fish farmers. The implication of the findings is that fish farmers whose secondary occupation takes more of his/her time and gives more revenue are less likely to be concerned about the adoption of any improved aquaculture technology. Also, the higher the income level of a fish farmer from fish farming, the more he will be willing to adopt improved aquaculture technologies as he will be able to afford the technologies unlike those who earn less from fish farming and perceive the fish farming as a non-profitable venture. The more the profit realized by the fish farmers, the more the likelihood that they will adopt more improved aquaculture technologies. This indicates that the mere awareness and availability of a technology does not imply that end users like fish farmers will make use of it because according to Ogunremi and Oladele (2012), who cited Adeshinwa and Bolorunduro (2007), some personal and socio-cultural factors have influence on the clienteles' decision to adopt a technology or not, even when it is readily available and appropriate. 
Table 7. Result of regression analysis of the relationship between socio-economic and production characteristics of the fish farmers and their adoption of improved aquaculture technologies

\begin{tabular}{|c|c|c|c|c|}
\hline & \multicolumn{2}{|c|}{ Un- standardized Coefficients } & \multirow{2}{*}{$\begin{array}{c}\text { Standardized } \\
\text { Coefficients } \\
\text { Beta } \\
\end{array}$} & \multirow{2}{*}{$\mathrm{T}$} \\
\hline & $\mathrm{B}$ & Std. Error & & \\
\hline (Constant) & 102.862 & 60.689 & & 1.695 \\
\hline Age & 5.088 & 3.528 & .248 & 1.442 \\
\hline Number of wives & -7.644 & 12.137 & -.267 & -.630 \\
\hline Number of children & -1.103 & 3.860 & -.152 & -.286 \\
\hline Number of other relations & -2.543 & 3.577 & -.353 & -.711 \\
\hline Total household size & 1.709 & 3.174 & .401 & .538 \\
\hline Education status & .103 & 3.710 & .007 & .028 \\
\hline Training acquired & -.996 & 5.484 & -.031 & -.182 \\
\hline Other occupation & -5.403 & 3.017 & -.324 & $-1.791^{*}$ \\
\hline Extension agent visit & -2.442 & 2.334 & -.192 & -1.046 \\
\hline Income level per annum & -5.532 & 2.696 & -.471 & $-2.052 * *$ \\
\hline Credits obtained & -.004 & 2.900 & .000 & -.001 \\
\hline Interest rate & -3.628 & 3.384 & -.179 & -1.072 \\
\hline Payback period & -6.897 & 4.809 & -.281 & -1.434 \\
\hline Output last year & 6.256 & 5.969 & .290 & 1.048 \\
\hline Price/kg or Price/hand of fish & -8.771 & 6.880 & -.224 & -1.275 \\
\hline Cost of pond construction & 5.249 & 2.310 & .477 & $273 * *$ \\
\hline Cost of pond management & -2.966 & 1.836 & -.283 & -1.615 \\
\hline Cost of fish fingerlings last year & 4.949 & 1.919 & .599 & 2.579 \\
\hline Total profit realized last year & -4.590 & 291 & -.466 & $-2.004 * *$ \\
\hline Fish farming experience & 1.893 & 3.325 & .086 & .569 \\
\hline Farm size per ha & .943 & 6.967 & .030 & .135 \\
\hline Number of ponds & 1.450 & 1.465 & .191 & .990 \\
\hline Extension contact & -1.368 & 2.940 & -.089 & -.465 \\
\hline
\end{tabular}

\section{Conclusion and recommendations}

The study revealed that fish production is dominated by married persons (84) who were mainly men (75) with mean age and fishing experience of $45.14 \pm 8.45$ years and $5.72 \pm 2.12$ years, respectively. More than half (50) and about one-third (30) of the fish farmers sourced credit facilities from cooperative societies and Esusu, respectively, while 80 out of the 90 fish farmers sold their fishes as smoked fish. All the 90 fish farmers were aware of extension agents and their services, while 66 of the fish farmers were visited by extension agents on a forthnight basis. Aside from extension agents, 52 out of the 90 fish farmers also sourced information on aquaculture technologies from radio and television broadcasting. At least 81 of the fish farmers assessed extension services received as good.
Higher proportions of the fish farmers were aware, tried and adopted most of the improved aquaculture technologies with some of the fish farmers also discontinuing most of the previously adopted technologies.

This study therefore concluded that fish production is still primarily operated on small scale and that adoption of improved aquaculture technologies in Lagos State followed a series of stages in a systematic manner like any other technology or innovation adoption process. It follows that although the technologies were disseminated and demonstrated to fish farmers, not all the fish farmers adopted the technologies at the same rate. The study also concluded that the adoption of improved aquaculture technologies is dynamic and highly influenced by socioeconomic characteristics of the fish farmers which also change with time. The study indicated that while all the 
fish farmers were aware, tried and even adopted some technologies, those technologies were later discontinued by most of the fish farmers who had previously adopted those technologies. It can also be concluded from the study that technologies that were easily adopted after the trial stage were highly discontinued after some time, unlike those technologies that did not receive a high level of adoption after trial.

It can therefore be recommended that in the adoption of improved aquaculture technologies like any other technology, fish farmers should take their time to pass through the key stages of adoption in a step-wise manner so that they are fully convinced of Stage 1 before moving forward to Stage 2 and so on. It is also recommended that technologies that do not receive high awareness among the fish farmers should be re-introduced and popularized among them and that the strengths of the technologies should be duly demonstrated while also displaying the possible opportunities that the fish farmers will benefit from through the adoption of such improved aquaculture technologies. Finally, technologies that received low level of adoption or which discontinued after earlier adoption should be worked on so that the adoption of those technologies will translate to increased income level of fish farmers, reduced cost of pond construction and increased profit of the fish farmers.

\section{Sažetak}

\section{DINAMIKA USVAJANJA POBOLJŠANIH TEHNOLOGIJA AKVAKULTURE MEĐU UZGAJIVAČIMA RIBE U LAGOSU U NIGERIJI}

Studija ocjenjuje usvajanje poboljšanih tehnologija akvakulture među uzgajivačima ribe u Lagosu u Nigeriji. Ukupno 90 uzgajivača ribe uzorkovano je kroz višestupanjske tehnike uzorkovanja. Validirani i predtestirani raspored intervjua je korišten za dobivanje primarnih informacija od uzgajivača ribe. Dobiveni podaci obrađeni su deskriptivnom i inferencijalnom statistikom. Dobiveni rezultati pokazuju da je više od pola uzgajivača ribe dobilo kreditne pogodnosti od kooperativnih društava te oko jedne trećine od Esusa, dok su gotovo svi prodavali svoje ribe kao dimljene. Veći udio uzgajivača ribe su bili svjesni, pokušali su i usvojili većinu poboljšanih tehnologija akvakulture, dok su neki uzgajivači ribe obustavili većinu ranije usvojenih tehnologija. Ova studija također ukazuje da su uzgajivači riba imali pozitivan stav prema usvajanju poboljšanih tehnologija akvakulture. Rezultati regresijske analize su pokazali da su sekundarno zanimanje uzgajivača ribe $(\beta=-0,324$, $p<0,01)$, godišnja razina prihoda $(\beta=-0,471, p<0,05)$, trošak gradnje ribnjaka $(\beta=0,477, p<0,05)$ i ukupna ostvarena dobit $(\beta=-0,466, p<0,05)$ bili značajni prediktori usvajanja poboljšanih tehnologija od strane uzgajivača ribe s R2, što pokazuje da je 46,0\% varijabilnosti u donošenju poboljšanih tehnologija akvakulture objašnjeno društvenoekonomskim i proizvodnim karakteristikama uzgajivača ribe. Zaključak studije je da je usvajanje poboljšanih tehnologija akvakulture dinamično i značajno pod utjecajem socioekonomskih karakteristika uzgajivača ribe koje se također mijenjaju s vremenom. Stoga se preporučuje da se poradi na tehnologijama koje su dobile nisku razinu prihvaćanja ili koje su prekinute nakon prethodnih usvajanja, tako da se usvajanje tih tehnologija odrazi na povećanu razinu dohotka, smanjene troškove izgradnje ribnjaka i povećanje profita uzgajivača ribe.

Ključne riječi: usvajanje tehnologija, akvakultura, obustava, dinamika, riblje nastambe, Nigerija

\section{REFERENCES}

Adeshinwa, A. O. K., Bolorunduro, P. I. (2007): Existing fisheries technologies and approaches for dissemination in two maritime States of Nigeria: Effectiveness and constraints. American-Eurasian J. Agric \& Environ. Sci., 2, 3, 231-239.

Adewuyi, S. A., Phillip, B. B., Ayinde, I. A., Akerele, D. (2010): Analysis of profitability of fish farming in Ogun State, Nigeria. Journal of Human Ecology, 31,3, 179-184.

Akegbejo-Samsons, Y. (1997): Introduction to aquaculture and fisheries management in Nigeria. Abeokuta. Good education Publishers, 87pp.

Ande, C. E. (2008): Essential Economics for senior secondary schools ( $2^{\text {nd }}$ edition). Ogun State, Nigeria: TONAD Publishers Limited, 157pp.

Agbebi, F. O. (2012). Assessment of the impact of extension services on fish farming in Ekiti State, Nigeria. Asian Journal of Agriculture and Rural Development, 2, 1, 62-68.

Areola, F. O. (2007): Fish marketing and export potentials of fish and fisheries products of Nigeria. A lecture delivered at educative and informative aquaculture workshop and aqua-exhibitions tagged: sustainable fisheries livelihood, management and food security in Nigeria, 23pp.

Baruwa, O. I., Tijani, A. A., Adejobi, A. O. (2012): Profitability and constraints to fishery enterprises: A case of artisanal and aquaculture fisheries in Lagos State, Nigeria. Nigerian Journal of Agriculture, Food and Environment, 8, 1, 52-58.

Federal Department of Fisheries - FDF (2007): Fisheries statistics of Nigeria. Federal Department of Fisheries Publication. Abuja, FCT, Nigeria, 11-24.

Federal Department of Fisheries - FDF (2008): Fisheries statistics of Nigeria. Fourth edition, 1995-2007, Nigeria, 48pp.

Federal Department of Fisheries - FDF (2009): Fisheries Development in Nigeria: the current challenges. Paper presented by the Honourable of State for Agriculture to the Fisheries Society of Nigeria (FISON), Lagos State, 23pp.

Food and Agriculture Organization - FAO (2006): State of 
world aquaculture 2006. FAO fisheries Technical Paper 500. FAO Inland water resources and aquaculture service, Fishery Resources Division, Rome, 147pp.

Food and Agriculture Organization - FAO (2013): FAO country programming framework (CPF). Federal Republic of Nigeria, Fiat Panis, 1-41.

Idowu, A. A. (2013): Culturable fish species, culture systems and medium management. A paper presented at a training workshop on sustainable fish farming for a secured future in Nigeria Organised by Agricultural Media Resources and Extension Centre, Federal University of Agriculture Abeokuta, $5 \mathrm{pp}$.

Ifejika, P. I., Ayanda, J. O. (2012): Influence of NIFFR training on attitude of civil servants toward fish farming enterprise in Niger State, Nigeria. Journal of Applied Agricultural Research, 4, 1, 33-39.

Kolawole, O. D., Williams, S. B., Awujola, A. F. (2010): Indigenous fish processing and preservation practices amongst women in Southwestern Nigeria. Indian Journal of traditional Knowledge, 9, 4, 668-672.

Kudi, T. M., Bako, F. P., Atala, T. K. (2008): Economics of fish production in Kaduna state, Nigeria. ARPN Journal of Agricultural and Biological Science, 3, 5\&6, 17-21.

Kudoro, F. (2013): Design and construction of fish ponds. A paper presented at a training workshop on sustainable fish farming for a secured future in Nigeria Organised by Agricultural Media Resources and Extension Centre, Federal University of Agriculture Abeokuta. 14pp.

Ogunremi, J. B., Oladele, O. I. (2012): Adoption of aquaculture technology by fish farmers in Lagos State, Nigeria. Life Science Journal, 9, 2, 430-434

Oladimeji, Y. U., Abdulsalam, Z., Damisa, M. A. (2013): Socio-economic characteristics and returns to rural artisanal fishery households in Asa and PatigiLocal Government Areas of Kwara State, Nigeria. International Journal of Science and Nature, 4, 3, 445-455.

Olaoye, O. J. (2010): Dynamics of the adoption process of improved fisheries technologies in Lagos and Ogun States, Nigeria. An unpublished Ph.D thesis submitted to the Department of Aquaculture and Fisheries Management, University of Agriculture, Abeokuta, 337pp.
Olaoye, O. J., Ashley-Dejo, S. S., Adekoya, E.O. (2014): Smallholder fish farmers' information and training needs in Ogun State of Nigeria. Global Journal of Science Frontier Research: Aquaculture and Veterinary, 14, 3, 1-10.

Olaoye, O. J., Ashley-Dejo, S. S., Fakoya, E. O., Ikeweinwe, N. B., Alegbeleye, W. O., Ashaolu, F. O., Adelaja, O. A. (2013): Assessment of socio-economic analysis of fish farming in Oyo State, Nigeria. Global Journal of Science Frontier Research Aquaculture and Veterinary, 13, 9, 45-55.

Olatunji, A. E. Olah, O. M. (2012): The socio-economic status of artisanal fishers in Cross River, Cross River State, Nigeria. World Journal of Fish and Marine Sciences, 4, 6, 672-678.

Omitoyin, S. A., Tosan, F. B. (2012): Potential impacts of climate change on livelihood and food security of artisanal fisher folks in Lagos State, Nigeria. Journal of Agricultural Science, 4, 9, 20-30.

Shettima, B. G., Mohammed, S. T., Ghide, A. A., Zindam, P. L. (2014): Analysis of socio-economic factors affecting artisanal fishermen around Lake Alau, Jere Local government Area of Borno State, Nigeria. Nigerian Journal of Fisheries and Aquaculture, 2, 1, 48-53.

Tiamiyu, S. A., Olaoye, O. J., Ashimolowo, O. R., Fakoya, E. O., Ojebiyi, W. G. (2015): Benefits derived from National Fadama Development Project II by fish farmers in Lagos State, Nigeria. International Journal of Fisheries and Aquaculture, 7, 4, 54-61.

Tobor, J. G. (1994): The fishing industry in Nigeria - Status and potential for self-sufficiency in fish production. Nigerian Institute for Oceanography and Marine research (NIOMR), Technical Paper 54.

Tunde, A. B., Kuton, M. P., Oladipo, A. A., Olasunkanmi, L. H. (2015): Economic analyze of costs and return of fish farming in Saki-East Local Government Area of Oyo State, Nigeria. Journal of Aquaculture Resources Development, 6(2), 306-310.

Yucel, G., Daalen, G. L. (2011): Exploratory analysis of the impact of information dynamics on innovation diffusion. Journal of Technological Forecasting and Social Change, 78, 2, 358-372. 